\title{
Sueño en otro idioma: de lengua y amor
}

En enero de 2017, el director Ernesto Contreras presentó su tercera película, Sueño en otro idioma, en el Festival de Cine de Sundance, en el cual resultó ganadora del Premio del Público para Mejor Película Extranjera de Drama. No obstante, su fecha de estreno en México fue hasta inicios de 2018, a través de la labor del Colectivo Cine Social (CCS), que programó una serie de proyecciones en la Cineteca Nacional y otras salas pequeñas, como parte del Ciclo Derechos Indígenas, cuyo objeto era mostrar la riqueza de las lenguas de los pueblos indígenas.

La trama gira alrededor de un joven lingüista, Martín (Fernando Álvarez Rebeil), quien enfrenta la problemática de que los dos últimos hablantes de la lengua zikril - creada ex professo para la cinta-, don Evaristo (Eligio Meléndez) y don Isauro (José Manuel Poncelis), se encuentran enemistados debido a problemas amorosos en su juventud. El investigador intenta recuperar la lengua mediante entrevistas y conversaciones, por lo que trata de ayudar a los hombres a resolver sus problemas, sin embargo, uno de ellos se muestra reacio y decide no colaborar con el trabajo. La historia se va entrelazando con escenas de la juventud de los ancianos, lo que permite una totalidad narrativa que va desentrañando la polémica central.

La cinta estuvo inspirada en una historia similar, la del ayapaneco, que se hizo viral en internet alrededor del 2010. Sucedía que los dos últimos hablantes de esta variante del zoque no intercambiaban palabra, pero, con el fin de recuperar su lengua, decidieron reconciliarse y accedieron a proporcionar entrevistas; incluso, en su lugar de origen, Ayapa, Tabasco, se fundó una escuela que lleva sus nombres: Don Manuel y Don Isidro. El director de la película ha declarado en entrevistas que 
cuando leyó esta noticia sintió que había en ella algo muy poderoso para contar; por eso decidió llevarla a la pantalla grande.

El estreno en México tuvo lugar en la sala 9 de la Cineteca Nacional, el sábado 27 de enero de 2018. Esta presentación contó con la presencia del poeta náhuatl Mardonio Carballo y el actor José Manuel Poncelis. La venta de boletos fue especial: además de ser una donación voluntaria sugerida, los fondos recaudados fueron asignados a la organización no gubernamental Psicología y Derechos Humanos A. C. (PSYDEH) También estuvieron presentes los colectivos indígenas Mujeres con Futuro, A. C., Flor del Bosque, A. C. y Nuevo Amanecer, A. C., en su mayoría conformados por mujeres, que forman parte de una red de organizaciones que colaboran con PSYDEH.

Al final del estreno hubo una reflexión sobre la importancia de las lenguas indígenas, y después nos trasladamos al Teatro La Capilla, donde se realizó un café-conversatorio, y se exhibió una muestra fotográfica de algunos de los proyectos llevados a cabo por las asociaciones mencionadas. Además, hubo una "venta consciente" de artesanías, que alentó un pago justo, y una dinámica de preguntas acotadas a cultura, lengua, economía, educación, entre otros temas, con algunas mujeres de las agrupaciones, en la que los asistentes tenían la oportunidad de tener un acercamiento personal con ellas.

Sueño en otro idioma es una historia sobre el amor y la lengua. Con una fotografía impresionante de apabullantes paisajes de la selva veracruzana y un acompañamiento musical de gran calidad; se exhibió en varios cines comerciales con muy buena recepción, tanto por parte de la crítica como por el público. Estuvo nominada en 14 categorías en los Premios Ariel de 2018, y resultó ganadora en seis: Mejor Película, Mejor Sonido, Mejor Guion Original, Mejor Música Original, Mejor Fotografía y Mejor Actor, reconocimiento que recibió Eligio Meléndez. Es una película llena de sorpresas y detalles, que, sin duda, vale la pena ver.

Giselle GonZÁlez Camacho 